\title{
POST-BARIATRIC SURGERY WEIGHT REGAIN: EVALUATION OF NUTRITIONAL PROFILE OF CANDIDATE PATIENTS FOR ENDOSCOPIC ARGON PLASMA COAGULATION
}

Reganho de peso após cirurgia bariátrica: avaliação do perfil nutricional dos pacientes candidatos ao procedimento de plasma endoscópico de argônio

Maria Paula Carlini CAMBI, Simone Dallegrave MARCHESINI, Giorgio Alfredo Pedroso BARETTA

From the Serviço de Endoscopia Digestiva, Hospital Vita Batel (Endoscopy Service, Vita Batel Hospital), Curitiba, PR, Brazil.
ABSTRACT - Background: Bariatric surgery is effective treatment for weight loss, but demand continuous nutritional care and physical activity. They regain weight happens with inadequate diets, physical inactivity and high alcohol consumption. Aim: To investigate in patients undergoing Roux-Y-of gastroplasty weight regain, nutritional deficiencies, candidates for the treatment with endoscopic argon plasma, the diameter of the gastrojejunostomy and the size of the gastric pouch at the time of treatment with plasma. Methods: A prospective 59 patients non-randomized study with no control group undergoing gastroplasty with recurrence of weight and candidates for the endoscopic procedure of argon plasma was realized. The surgical evaluation consisted of investigation of complications in the digestive system and verification of the increased diameter of the gastrojejunostomy. Nutritional evaluation was based on body mass index at the time of operation, in the minimum BMI achieved after and in which BMI was when making the procedure with plasma. The laboratory tests included hemoglobin, erythrocyte volume, ferritin, vitamin D, B12, iron, calcium, zinc and serum albumin. Clinical analysis was based on scheduled follow-up. Results: Of the 59 selected, five were men and 51 women; were included 49 people (four men and 44 women) with all the complete data. The exclusion was due to the lack of some of the laboratory tests. Of this total 19 patients (38.7\%) had a restrictive ring, while $30(61.2 \%)$ did not. Iron deficiency anemia was common; 30 patients (61.2\%) were below 30 with ferritin (unit); 35 (71.4\%) with vitamin B12 were below 300 pg/ $\mathrm{ml}$; vitamin D3 deficiency occurred in more than $90 \%$; there were no cases of deficiency of protein, calcium and zinc; glucose levels were above $99 \mathrm{mg} / \mathrm{dl}$ in three patients $(6.12 \%)$. Clinically all had complaints of labile memory, irritability and poor concentration. All reported that they stopped treatment with the multidisciplinary team in the first year after the operation. Conclusion: The profile of patients submitted to argon plasma procedure was: anastomosis in average with $27 \mathrm{~mm}$; multiple nutritional deficiencies with predominance of iron deficiency anemia; ferritin below 30; vitamin B12 levels below 300 $\mathrm{pg} / \mathrm{ml}$; labile memory complaints, irritability and poor concentration.
HEADINGS - Weight gain. Bariatric surgery. Endoscopy, gastrointestinal. Deficiency diseases.

\section{Correspondence:}

Maria Paula Carlini Cambi

E-mail:mpcarlini@hotmail.com

Financial source: none

Conflicts of interest: none

Received for publication: 18/09/2014 Accepted for publication: 09/12/2014
DESCRTORES - Ganho de peso. Cirurgia bariátrica. Endoscopia gastrointestinal. Deficiências nutricionais.
RESUMO - Racional: A cirurgia bariátrica é tratamento efetivo para a perda ponderal, mas demanda cuidados contínuos com a nutrição e a atividade física. A recidiva de peso é verificada quando há retorno aos hábitos alimentares errôneos, sedentarismo e alto consumo alcoólico. Objetivo: Investigar nos pacientes submetidos à gastroplastia em Y-de- Roux a recidiva de peso, as deficiências nutricionais, os candidatos ao tratamento de plasma endoscópico de argônio e o diâmetro da anastomose gastrojejunal no momento da realização do tratamento com plasma. Métodos: Estudo prospectivo não randomizado e sem grupo controle com 59 pacientes submetidos à gastroplastia, com recidiva de peso e candidatos ao procedimento endoscópico de plasma de argônio. A avaliação cirúrgica constou de investigação de complicações no aparelho digestório e verificação do aumento do diâmetro da anastomose gastrojejunal. A nutricional foi baseada no índice de massa corporal no momento da operação, o IMC mínimo que o paciente chegou após ela e o IMC em que se encontrava no momento de realizar procedimento com plasma. A análise laboratorial incluiu hemoglobina, volume globular, ferritina, vitaminas $\mathrm{D}, \mathrm{B}_{12}$, ferro, cálcio, albumina sérica e zinco. A análise de seguimento baseou-se nos retornos programados. Resultados: Dos 59 selecionados, cinco eram homens e 51 mulheres. Foram incluídos 49 pessoas (quatro homens e 44 mulheres) de ambos os sexos com todos os dados completos. A exclusão ocorreu pela falta de alguns dos exames laboratoriais. Deste total ao fazer o procedimento, 19 pacientes $(38,7 \%)$ possuíam o anel restritivo, enquanto 30 $(61,2 \%)$ não. Anemia ferropriva foi quadro comum; 30 pacientes $(61,2 \%)$ encontravam-se com ferritina abaixo de 30 (unidade); 35 (71,4\%) estavam com vitamina $B_{12}$ abaixo de 300 $\mathrm{pg} / \mathrm{ml}$; deficiência de vitamina $D_{3}$ ocorreu em mais de $90 \%$; não houve casos de deficiência de proteínas, cálcio e zinco; glicemia estava acima de $99 \mathrm{mg} / \mathrm{dl}$ em três pacientes $(6,12 \%)$. Clinicamente todos tinham queixas de memória lábil, irritabilidade e falta de concentração. Todos relataram abandono do tratamento com a equipe multiprofissional já no primeiro ano após a operação. Conclusão: Ao submeterem-se ao procedimento endoscópico com plasma de argônio por reganho de peso após gastroplastia as condições encontradas foram: anastomose com média de $27 \mathrm{~mm}$; múltiplas deficiências nutricionais com predomínio para anemia ferropriva; ferritina abaixo de 30; vitamina $B_{12}$ abaixo de $300 \mathrm{pg} /$ ml; queixas de memória lábil, irritabilidade e falta de concentração. 
B ariatric surgery, in its various forms, provides reduction in total caloric intake and decreases the absorption of macro- and micronutrients. It is known that this mechanical process, accompanied by changes in lifestyle - including regular physical activity and appropriate psychological treatment for the various nuances of compulsive eating - can be strong allies in the weight loss process.

However, bariatric surgery patients, after satisfactory weight loss, may regain weight if they go back to bad eating habits and sedentary lifestyle ${ }^{9,13,14,15,20}$. Other causes may be equally important factors for regaining weight, for example, excessive consumption of alcohol, craving for sweets or fattening foods in general, increase in the diameter of the gastrojejunal anastomosis and the length of the gastric pouch.

Weight regain may occur after satisfactory loss of excess weight or even before that if treatment in itself does not have its desired effect, resulting in insufficient weight loss. This process is perceived, but many patients do not seek necessary help from the attending staff for many reasons, among them the feeling of failure at the chance for effective weight loss so expected with the operation, which then becomes a nightmare.

Weight gain, in turn, can still result in nutritional consequences due to poor intestinal absorption caused by the majority of surgical techniques in the treatment of obesity. Although weight regain may represent a return to full energy utilization, many essential nutrients are still lost, which may result in severe iron-deficiency anemia, megaloblastic anemia, vitamin D deficiency and chronic malnutrition. This situation results in an obese individual with various nutritional complications that need to be addressed before considering weight loss per se.

The objective of this study was to investigate in patients who underwent Roux-en-Y gastric bypass (RYGB) the following aspects: weight regain, nutritional deficiencies, candidates for endoscopic argon plasma coagulation (APC), and the diameter of the gastrojejunal anastomosis at the time of APC.

METHOD

A non-randomized prospective study with no control group was conducted with 59 patients who underwent RYGB, had weight regain and were candidates for APC in the Hospital Vita Batel, Curitiba, Brazil in 2013. The study was approved by the Hospital Ethics Committee. The patients were evaluated by a multidisciplinary team; they were invited to participate and signed an informed consent form.

The surgeon's evaluation consisted of an investigation of the complications in the digestive system and determination of an increase in diameter of the anastomosis. Nutritional assessment was based on body mass index (BMI) that the patient had at the time of gastric bypass, the lowest BMI the patient achieved after the operation and BMI at the time of APC. The laboratory tests included hemoglobin, mean corpuscular volume, ferritin, vitamin $D_{\text {, vitamin }} B_{12}$, iron, calcium, zinc and serum albumin.

The results were analyzed using the mean values. Data were tabulated in a spreadsheet (Microsoft Excel, version 2007).
Of the 59 selected patients, eight were men and 51 women. Were included only 49 patients (five men and 44 women) who had complete data. Exclusion was due to the lack of some laboratory tests. On APC, 19 patients (38.7\%) had a gastric band, while 30 (61.2\%) did not.

TABLE 1 - Description of the patients included in the study $(n=49)$

\begin{tabular}{|c|c|c|c|}
\hline Parameter & $\begin{array}{c}\text { Mean } \pm \\
\text { Standard deviation }\end{array}$ & Maximum & Minimum \\
\hline Age (years) & $47 \pm 21$ & 68 & 26 \\
\hline Hemoglobin $(\mathrm{g} / \mathrm{dl})$ & $12.3 \pm 3.3$ & 15.7 & 9 \\
\hline Hematocrit $(\%)$ & $39.2 \pm 7.8$ & 47 & 31.4 \\
\hline Ferritin $(\mathrm{ng} / \mathrm{ml})$ & $112.4 \pm 110.5$ & 222.9 & 1.9 \\
\hline Vitamin $\mathrm{B}_{12}(\mathrm{pg} / \mathrm{ml})$ & $806 \pm 694$ & 1500 & 112 \\
\hline Iron $(\mathrm{mg} / \mathrm{l})$ & $99.7 \pm 77 . / 7$ & 177.4 & 22 \\
\hline Vitamin $\mathrm{D}_{3}$ & $20.2 \pm 14.9$ & 35.1 & 5.3 \\
\hline Calcium & $9.2 \pm 1.2$ & 10.4 & 8 \\
\hline Albumin & $4.2 \pm 0.5$ & 4.7 & 3.7 \\
\hline Glucose $(\mathrm{mg} / \mathrm{dl})$ & $132.3 \pm 51.6$ & 183.9 & 80.7 \\
\hline Zinc & $92.7 \pm 55.3$ & 148 & 37.4 \\
\hline BMI before surgery & $49.2 \pm 14.1$ & 63.3 & 35.1 \\
\hline (kg/m $\left.{ }^{2}\right)$ & $29 \pm 11.5$ & 40.5 & 17.5 \\
\hline BMI lowest after & & & \\
\hline surgery kg/m $\left.{ }^{2}\right)$ & $39.3 \pm 14.1$ & 53.4 & 25.2 \\
\hline BMI at time of APC & $27.5 \pm 12.5$ & 40 & 15 \\
\hline (kg/m ${ }^{2}$ ) & & & \\
\hline Anastomosis (mm) & & & \\
\hline
\end{tabular}

Iron-deficiency anemia was common in this population, and 30 patients (61.2\%) had a ferritin level less than $30 \mathrm{ng} / \mathrm{ml}$. Thirty-five $(71.4 \%)$ had a vitamin $B_{12}$ level below $300 \mathrm{pg} / \mathrm{ml}$. All had complaints of poor memory, irritability and lack of concentration.

All 49 patients included in the study reported that they stopped treatment with the multidisciplinary team in the first year after RYGB. Vitamin $D_{3}$ deficiency occurred in $90 \%$ of patients. There were no cases of protein, calcium or zinc deficiency. Blood glucose was above $99 \mathrm{mg} / \mathrm{dl}$ in three patients (6.12\%). BMI before surgery varied between high with severe obesity (BMI $35.1 \mathrm{~kg} / \mathrm{m}^{2}$ ) and very high with morbid obesity (BMI $63.3 \mathrm{~kg} / \mathrm{m}^{2}$ ). The lowest BMI after the operation ranged from normal (BMI $17.5 \mathrm{~kg} / \mathrm{m}^{2}$ ) to very high (BMI $40.5 \mathrm{~kg} / \mathrm{m}^{2}$ ). After weight regain at the time of APC, BMI ranged from normal (BMI $25.2 \mathrm{~kg} / \mathrm{m}^{2}$ ) to high again with obesity (BMI $53.4 \mathrm{~kg} / \mathrm{m}^{2}$ ). The anastomosis varied in the subjects included in the study. The mean diameter was $27 \mathrm{~mm}$, with the lowest value being $15 \mathrm{~mm}$ and the highest $40 \mathrm{~mm}$.

\section{DISCUSSION}

According to Blomain et al. ${ }^{5}$ and Bordallo et al. ${ }^{6}$, obesity is a global pandemic and is associated with comorbidities. With RYGB, many diseases are again under control, such as hypertension, diabetes mellitus and hepatic steatosis. But because of compensatory mechanisms and failure to make lifestyle changes, many patients regain weight and begin to have the same comorbidities as before, now along with serious nutritional deficiencies.

In this study, $100 \%$ quit follow-up with the attending staff. Many did not repeat examinations for years. They regained excess weight and then believed they were healthy, even though overweight.

Bariatric surgery resulted in satisfactory weight loss in most cases. The study group showed a significantly lower BMI after the operation. However, over time, the patients relapsed. Many explanations were given, such as 
return to poor eating habits, significant increase in alcohol consumption and physical inactivity.

Over time, there was a significant reduction in BMI and with it the individual's expectation that the disease of obesity would be cured. In one case, the individual's BMI decreased from $63.3 \mathrm{~kg} / \mathrm{m}^{2}$ to $40.5 \mathrm{~kg} / \mathrm{m}^{2}$, which already showed quite effective weight loss.

The cure of comorbidities was also experienced by those who lost weight, but after relapse, many again had abnormalities in glucose and lipid metabolism. In the study group, three patients again had changes in blood glucose and were at risk for diabetes after regaining excess weight.

After the "honeymoon" of bariatric surgery, the first signs that something was wrong were the numbers on the scale rising rapidly, and why would this be happening? It was probably because of going back to poor eating habits, facilitating the increase in the size of the anastomosis, which greatly facilitates the entry of more extra calories. At this time, there was the possibility of APC, which would be a quick, effective, noninvasive solution that could be another attempt at weight control.

According to Marchesini et al. ${ }^{15}$, APC is performed by endoscopy, where the endoscopist surgeon uses argon gas to cause a "burn" in the region of the enlarged anastomosis to promote healing to decrease the size of the anastomosis, minimizing the gastric emptying rate. This process aims to increase the patient's satiety and facilitate weight loss. This should be done only in people who have had bariatric surgery.

In this study population who experienced weight regain, $B M I$ at the time of $A P C$ ranged from normal (BMI $25.2 \mathrm{~kg} / \mathrm{m}^{2}$ ) to very high again with obesity (BMI $53.4 \mathrm{~kg} /$ $\mathrm{m}^{2}$ ). The study by Correia Horvath et al. ${ }^{8}$, who recruited 77 operated patients, found deficiency of potassium in $19 \%$ of respondents, of calcium in $26 \%$ and of iron in $66.2 \%$. Even with weight regain, patients still had nutritional deficiencies. The general condition of most of them always involved some deficiency, severe anemia and vitamin $D_{3}$ insufficiency. In the present study. there was iron deficiency in $61.2 \%$. The occurrence of anemia, both irondeficiency and megaloblastic, was quite common after RYGB, in which there is substantial loss in absorption sites for these nutrients. Decreases in intrinsic factor and ileum for absorption of vitamin $\mathrm{B}_{12}$ are also determining factors. Women of reproductive age may have substantial changes in their menstrual cycle and exacerbated flow and more days of bleeding, which greatly hamper the use of iron. In parallel with the lack of nutritional supplements taken by mouth or intravenously, anemia becomes serious and debilitating.

Another common nutritional deficiency, also found in individuals not operated, is vitamin $D_{3}$. In the subjects studied were, $100 \%$ had a nutritional deficiency. There was a lack of regular sun exposure and diet records included few sources of vitamin $D_{3}$.

Bariatric surgery reduces excess weight, but relapse can be observed after a period of five years, especially with the return to the previous dietary pattern as described by Bastos et al. ${ }^{3}$

Foods with high satiety, such as those high in protein and fiber and with low caloric density (fruits and vegetables), may not be well tolerated after the operation, particularly due to the lack of proper chewing and of concomitant fluid intake. Johnson Stoklossa and Atwal ${ }^{12}$ referred to apples as an example, where one has only 78 $\mathrm{kcal}$ and needs to be well chewed to be of value, versus $118 \mathrm{kcal}$ for apple juice, which does not require any effort to be digested.
The wrong nutritional selection regarding soft foods can cause weight gain. Eating less fruits causes a decrease in fiber intake and, consequently, vitamins and minerals.

This study did not determine the nutritional value of daily caloric intake, but was noticed a sharp change in food consistency to soft foods high in calories, use of chocolate and soft sweets in general, as well as inclusion of alcoholic beverages in large amounts and daily, which greatly surpassed the recommended daily caloric intake.

Adaptive thermogenesis is decreased after weight loss. There is decreased resting energy expenditure and there may be changes in fat and muscle mass.

Meguid et al. ${ }^{16}$ reported that weight regain occurs in $20 \%$ of patients two to three years after RYGB and that it is a serious complication. It leads to consequences that are attributed to a diminished peptide $Y Y$ concentration, indicating that the combination of RYGB and pharmacological stimulation with peptide $Y Y$ can promote weight loss.

Stewart et al. ${ }^{19}$, in an inspiring paper called "Back on track", proposed that bariatric patients who regained weight after the operation need to resume care under the multidisciplinary team. Simple and effective measures are mentioned, such as proper chewing, better food choices, back to regular physical activity and treatment of compulsions.

Nutritional counseling was offered to all patients who underwent APC to treat weight regain and were included in this study. They were encouraged to return to careful eating and regular physical exercise, as well as to use more willpower. All had a psychological evaluation.

Chapman et al. ${ }^{7}$ described lifestyle as being responsible for the recurrence of weight gain, including watching television, drinking alcohol, sleep deprivation, which are not correlated with obesity but favor high caloric intake. These habits are known to affect cognitive function, involving inhibitory control and it is a common mechanism facilitating overeating. In this study, protein or caloric intake was not evaluated.

It is important to realize that all patients in the study, at some point after weight loss, abandoned follow-up with the multidisciplinary team. This was a determining factor for weight regain, especially when they saw that they had lost the excess weight and thought that they could ignore the guidelines outlined by the staff before the operation. Resuming office visits and seeking good advice from trained professionals would be a good way of getting "back on track" to lose weight and maintain a healthy weight.

\section{CONCLUSIONS}

On APC for weight regain after gastric bypass, the conditions found were: anastomosis with a mean of $27 \mathrm{~mm}$; multiple nutritional deficiencies with a predominance of iron-deficiency anemia; ferritin below $30 \mathrm{ng} / \mathrm{ml}$; $B_{12}$ below $300 \mathrm{pg} / \mathrm{ml}$; and complaints of poor memory, irritability and lack of concentration.

\section{REFERENCES}

1. Aills L, Blankenship J, Buffington C, Furtado M, Parrott J. ASMBS Allied Health Nutritional Guidelines for the Surgical Weight Loss Patient. Surg Obes Relat Dis. 2008 Sep-Oct;4(5 Suppl):S73-108.

2. Allison DB, Mattes RD. Nutritively sweetened beverage consumption and obesity: the need for solid evidence on a fluid issue. JAMA. 2009 Jan 21;301(3):318-20.. 
3. Bastos EC, Barbosa EM, Soriano GM, dos Santos EA, Vasconcelos $\mathrm{SM}$. Determinants of weight regain after bariatric surgery. Arq Bras Cir Dig. 2013;26 Suppl 1:26-32.

4. Becker DA, Balcer LJ, Galetta SL. The Neurological Complications of Nutritional Deficiency following Bariatric Surgery. J Obes. 2012;2012:608534.

5. Blomain ES, Dirhan DA, Valentino MA, Kim GW, Waldman SA Mechanisms of weight regain following weight loss. ISRN Obes. 2013; 2013(210524):1-7.

6. Bordalo LA, Mourão DM, Bressan J. Deficiências nutricionais após cirurgia bariátrica. Por que ccorrem? Acta Med Port. 2011 24(S4):1021-1028.

7. Chapman $C D$, Benedict $C$, Brooks SJ, Schiöth HB. Lifestyle determinants of the drive to eat: a meta-analysis. Am J Clin Nutr. 2012 Sep;96(3):492-7..

8. Correia Horvath JD, Dias de Castro ML, Kops N, Kruger Malinoski $\mathrm{N}$, Friedman R. Obesity coexists with malnutrition? Adequacy of food consumption by severely obese patients to dietary reference intake recommendations. Nutr Hosp. 2014 Feb 1;29(2):292-9.

9. Costa LD, Valezi AC, Matsuo T, Dichi I, Dichi JB. Nutritional and metabolic evaluation of patients after one year of gastric bypass surgery. Rev Col Bras Cir. 2010 Apr;37(2):96-101.

10. Faria SL, Kelly E, Faria OP. Energy expenditure and weight regain in patients submitted to Roux-en-Y gastric bypass. Obes Surg. 2009 Jul;19(7):856-9.

11. Heber D, Greenway FL, Kaplan LM, Livingston E, Salvador J, Still C Endocrine Society. Endocrine and nutritional management of the post-bariatric surgery patient: an Endocrine Society Clinical Practice Guideline. J Clin Endocrinol Metab. 2010 Nov;95(11):4823-43.

12. Johnson Stoklossa C, Atwal S. Nutrition care for patients with weight regain after bariatric surgery. Gastroenterol Res Pract. 2013;2013:256145.
13. Joia-Neto L, Lopes-Junior AG, Jacob CE. Digestive and metabolic changes in postoperative bariatric surgery. Arq Bras Cir Dig, 2010;23(4):266-9

14. Marchesini JB, Nicareta JR. Comparative study of five different surgical techniques for the treatment of morbid obesity using BAROS. Arq Bras Cir Dig. 2014;27 Suppl 1:17-20.

15. Marchesini SD, Baretta GA, Cambi MP, Marchesini JB. Endoscopic plasma argon coagulation in treatment of weight regain after bariatric surgery: what does the patient think about this? Arq Bras Cir Dig. 2014;27 Suppl 1:47-50.

16. Meguid MM, Glade MJ, Middleton FA. Weight regain after Rouxen-Y: a significant 20\% complication related to PYY. Nutrition. 2008 Sep;24(9):832-42.

17. Pajari M, Pietiläinen KH, Kaprio J, Rose RJ, Saarni SE. The effect of alcohol consumption on later obesity in early adulthood--a population-based longitudinal study. Alcohol Alcohol. 2010 MarApr;45(2):173-9.

18. Schweiger C, Weiss R, Keidar A. Effect of different bariatric operations on food tolerance and quality of eating. Obes Surg. 2010 Oct;20(10):1393-9.

19. Stewart KE, Olbrisch ME, Bean MK. Back on track: confronting post surgical weight gain. Bariatric Nursing and Surgical Patient Care. June 2010,5(2):179-185.

20. Valezi AC, Brito EM, Souza JCL, Guariente ALM, Emori FT, Lopes VCH. The importance of the silastic ring in the ROUX-en-Y gastric bypass for the treatment of obesity. Rev Col Bras Cir. 2008:35(1)18-22.

21. Yeomans MR. Alcohol, appetite and energy balance: is alcohol intake a risk factor for obesity? Physiol Behav. 2010 Apr 26;100(1):82-9. 